\title{
Feasibility of different crop rotations for cultivation in salt affected soils
}

\author{
Khalil AHMED $^{1,2}$, Ghulam QADIR ${ }^{1}$, Muhammad Qaisar NAWAZ ${ }^{1}$, Muhammad SARFRAZ ${ }^{1}$, Muham- \\ mad RIZWAN ${ }^{1}$, Muhammad Anwar ZAKA ${ }^{1}$, Sarfraz HUSSAIN ${ }^{1}$
}

Received June 03, 2018; accepted July 29, 2019.

Delo je prispelo 03. junija 2018, sprejeto 29. julija 2019.

\section{Feasibility of different crop rotations for cultivation in salt af- fected soils}

Abstract: Crop rotation can be used as an effective technique for managing salt-affected soils, however selection of suitable crop rotation at farmer field is very intricate decision which depends on expected net revenue, available resources and preserving the soil quality. In this perspective a study was conducted to evaluate a suitable crop rotation scheme for salt affected soils in term of economic value and improving the soil health. Seven crop rotation used were; $\mathrm{T}_{1}=$ WheatRice, $\mathrm{T}_{2}=$ Wheat-Sesamum, $\mathrm{T}_{3}=$ Ispagol-Rice, $\mathrm{T}_{4}=$ IspagolQulfa, $\mathrm{T}_{5}=$ Tukhum-e-blangoo-Qulfa, $\mathrm{T}_{6}=$ Ajwain-Niazboo, $\mathrm{T}_{7}=$ Saunf-Podina. A moderately salt affected field $\left\{\mathrm{pH}_{\mathrm{s}}=8.65\right.$, $\left.\mathrm{EC}_{\mathrm{e}} 5.20 \mathrm{dS} \mathrm{m}^{-1}, \mathrm{SAR}=27.73\left(\mathrm{mmol} \mathrm{l}^{-1}\right)^{1 / 2}\right\}$ was selected. The experimental design was randomized complete block design (RCBD) with three replications having plot size of $4 \mathrm{~m} \mathrm{x} 6 \mathrm{~m}$. Results of two years study showed that maximum grain yield was recorded by rice wheat rotation and maximum net income (208352 Rs. ha ${ }^{-1}$ ) and BCR (4.72) was also observed in ricewheat crop rotation over all other crop rotations. With respect to ameliorative affect, rice- wheat rotation also showed a significant positive impact on chemical properties of salt affected soil. Therefore, it is suggested that rice wheat crop rotation is the most suitable and economically attractive cropping scheme in salt affected soil which has potential to provide better longterm income to farmers, improve soil health and combat soil deterioration caused by salinity.

Key words: crop rotation; rice; wheat; salinity; cost benefit
Primernost različnih kolobarjev za pridelavo na slanih tleh Izvleček: Kolobarjenje lahko uporabimo kot učinkovito tehniko za obvladovanje učinka slanosti tal, vendar je izbira ustreznega kolobarjenja za kmeta zelo zapletena odločitev, ki zavisi od pričakovanega neto dohodka, razpoložljivih sredstev in ohranjanja kakovosti tal. V povezavi s to tematiko je bila izvedena študija, katere namen je bil ovrednotiti primernost različnih načinov kolobarjenja na slanih tleh $\mathrm{z}$ ekonomskega vidika in vidika izboljšanja uporabnosti tal. Uporabljenih je bilo naslednjih sedem načinov kolobarjenja: $\mathrm{T} 1$ = pšenica $($ Triticum aestivum L.) - riž (Oryza sativa L.), T2 = pšenica - sezam (Sesamum indicum L.), T3 = indijski trpotec (Plantago ovata Forssk.) - riž, T4 = indijski trpotec - navadni tolščak (Portulaca oleracea $\mathrm{L}$.), T5 = lalemancija (Lallemantia royleana Benth. in Wall.) - navadni tolščak, T6 = iranska kumina (Carum copticum L.) - navadna bazilika (Ocimum basilicum L.), T7 = navadni komarček (Foeniculum vulgare Mill.) - poprova meta (Mentha piperita L.). Izbrana so bila zmerno slana tla $(\mathrm{pHs}=8.65, \mathrm{ECe}=$ $5.20 \mathrm{dS} \mathrm{m}^{-1}$, SAR $\left.=27.73\left(\mathrm{mmol} \mathrm{l}^{-1}\right)^{1 / 2}\right)$. Poskus je bil zasnovan $\mathrm{v}$ naključnem bločnem razporedu (RCBD) s tremi ponovitvami in velikostjo parcelic $4 \mathrm{~m} \times 6 \mathrm{~m}$. Rezultati dvoletnega poskusa so pokazali, da je bil v kolobarju riža s pšenico dosežen največji pridelek zrnja in največji neto dohodek (208352 Rs. ha $\left.{ }^{-1}\right)$ kot tudi največji količnik med stroški in prihodkom (BCR; 4.72). Kolobar riža s pšenico je pokazal tudi značilne pozitivne učinke na kemijske lastnosti slanih tal. Zaradi naštetega se za načrtovanje rotacije poljščin na slanih tleh priporoča kolobar riža $s$ pšenico kot najbolj primeren in ekonomnsko najbolj obetaven, saj ima večji potencial dolgoročnega zagotavljanja prihodkov kmetov, izboljšuje lastnosti slanih tal in zmanjšuje verjetnost njihovega slabšanja. hodki 


\section{INTRODUCTION}

A key challenge of 21 st century agriculture is to provide the food, fiber and fuel for an expanding population while preserving the soil fertility and providing adequate farm profitability to farmers (Robertson and Swinton, 2005). Furthermore, agricultural land loss due to salinity is one of the main problems to sustainable agriculture as approximately $20 \%$ of the world's cultivated land are salt affected (Sumner, 2000). In general, continued irrigation with poor quality ground water, poor infield management and a deficient drainage system are main causes of expansion of land salinization (Gehad, 2003). So in current scenario salt-affected soils are of growing importance to meet food demand of growing population and this situation necessitates some forward planning and need to find out several management and agronomic practices that work satisfactory for utilizing and preserving this natural resource (Gehad, 2003).

Rice (Oryza sativa L.), cultivation started nearly 11,500 years ago (Gnanamanickam, 2009) and approximately half of the world's population consumed the rice as staple food (Ma et al., 2007). To ensure food security for the expanding population, rice production should be increased by $50 \%$ in rice consuming countries (Jinni and Joseph, 2017). Wheat (Triticum aestivum L.), is also a main vegetable protein source and is cultivated all around the world due to its adaptation to a various range of climates. Globally it is a major food crop, which is cultivated on approximately 200 million hectares with an average production of 600 million tons (Rajarm \& Braun, 2006). Medicinal plants are also becoming increasingly popular in modern society and are used all over the world as natural alternatives to synthetic chemicals (Wyk \& Wink, 2004). It may be worthwhile to explore potential of medicinal plants for salt affected soil, which may be beneficial for mankind. Previously many researchers have described the economical and medicinal importance of several halophytes (Dagar, 1995). Consequently, concerted research efforts are required for their immense potential to be planted on salt affected soils as valuable resource and cash crop on an urgent basis.

Crop rotation is an agricultural practice, which implicates cultivation of different crops on same field. Selection of suitable crop rotation at farmer field is very intricate decision. Economists assume that farmers tend to pursue activities that improve their utility, or well-being, generate revenue, lessen the monetary and physical risk, decrease labor demands, and are comfortable or pleasurable (Bowman and Zilberman, 2013). One of the main issues influencing crop production choices by farmers is the expected market price of selected commodity and the resulting estimated net revenue, in addition to the rela- tive economic risk associated with production of potential commodities (Huirne et al., 2000). A farmer's earnings and capacity to achieve credit, farming systems, skill and technologies and willingness to invest in new crops will also influence the choice of crops (Knowler and Bradshaw, 2007; Salassi et al., 2013). In a study consisting of different crop rotation Dogan et al. (2008) reported that wheat and sunflower using as main crop were more profitable rotation system under rain fed conditions having net profit of $\$ 474$ and $\$ 482 \mathrm{ha}^{-1}$ year $^{-1}$, respectively. Likewise, Nel and Loubser (2004) stated that crop rotation consisting of sunflower, soyabean were most effective rotations with maximum net while mitigating financial risk. Similarly, a field trail showed that inclusion of oilseeds crop in cereals generate the maximum net return, reducing the financial risk through improved production stability (Dhuyvetter et al., 1996). To evaluate the economic assessment of different crop rotation consisting of: corn-soybean-corn (CSC), alfalfa-alfalfa-corn (AAC), continuous corn (CCC), soybean-wheat-corn (SWC), soybean-corn- corn (SCC) and soybean-alfalfa-corn (SAC). Goplen et al. (2018) reported that alfalfa-alfalfa-corn (AAC) was most dominant crop rotation with the highest net return of $\$ 919 \mathrm{ha}^{-1} \mathrm{yr}^{-1}$, mostly due to more stable prices of alfalfa. Jat et al. (2012) studied the economic performance of ten rice-based cropping sequences. Results revealed that rice - fenugreek - okra was most productive $\left(25.73 \mathrm{tha}^{-1}\right)$ cropping system with maximum return of $\left(96,286 \mathrm{Rs} \mathrm{ha}^{-1}\right)$.

However, in salt affected soils there is need to combine profitability in combination with other production factors like soil remediation, soil fertility and soil physical and chemical properties (Popp et al., 2005; Yao et al. 2013). Furthermore, crop rotation could be used as an alternative approach to improve soil health and combat soil deterioration. It improves soil structure (Yazar, 2008), increases soil organic matter (Bremer et al., 2008; Bhatti and Khan, 2012) and water use efficiency (Tanaka et al., 2005), improves crop nutrient use efficiency (Karlen et al., 1994), reduces grain yield variability (Varvel, 2000) and improves grain quality (Kaye et al., 2007).

Furthermore, when good quality water supplies are limited a suitable crop rotation is the only means for managing salt-affected soils and maintaining crop yields (Kaur et al., 2007). Crop rotation resulted in several improvements, in soil physical and chemical properties and is also suggested for salt affected soil, especially when crops with varying degrees of salinity tolerance are used (Lacerda et al., 2011). For suitable crop rotation in salt affected soils, selected crop should be either salt tolerant or tolerant cultivars must be selected from sensitive or medium tolerant crops with high economic value (Ouda et al., 2016; Kishk, 2000). Likewise, appropriate crop ro- 
tation in salt-affected soils can accelerate the reclamation process by reducing evaporation and upward transport of salt in the soil (Brady and Well, 2008).

Abro and Mahar (2007) reported that in rice-wheat cropping system, salinity indicators like soil $\mathrm{EC}_{\mathrm{e}}, \mathrm{pH}$ and SAR were significantly lowered after the rice harvest, however, a minor increase in $\mathrm{EC}_{\mathrm{e}}$ and $\mathrm{pH}$ were recorded whereas, the SAR levels dwindled further after wheat harvest. Similarly in a study Liu et al. (2013) reported that the rice-barley crop rotation lowered soil $\mathrm{EC}_{e}$ after a reclamation time of more than 10 years. Zhang and $\mathrm{He}$ (2004) found that rice plantation resulted the addition of soil organic matter. The paddy soil management for 50 years favored the enhancement of soil organic carbon and decreased the concentrations of $\mathrm{Ca}, \mathrm{Mg}$, and $\mathrm{Na}$ (Chen et al., 2011). Fu et al. (2014) found that rice-barley crop rotation had more ameliorative effect on soil properties and significantly decreased the $\mathrm{pH}$ value than cotton-barley crop rotation system at the same year. Similarly, in a study Zou et al. (2011) concluded that the management of rice crop increased the accumulation of organic matter, which tends to converge soil $\mathrm{pH}$ to neutral. In addition, leaching effects of irrigation reduces the soil salinity (Iost et al., 2007; Fu et al., 2012).

So, keeping the all above facts in consideration the work presented in this paper was designed to evaluate a suitable crop rotation scheme for salt affected soils which will not only benefit the overall productivity and profitably of the farm but also improve the soil health.

\section{MATERIAL AND METHODS}

This field trial was conducted for two successive seasons from 2011-12 to 2012-13 at Soil Salinity Research Institute Pindi Bhattian. A moderately salt affected field $\left\{\mathrm{pH}\right.$ of soil saturated past $\left(\mathrm{pH}_{\mathrm{s}}\right)=8.65$, electrical conductivity of soil extract $\left(\mathrm{EC}_{\mathrm{e}}\right)=5.20 \mathrm{dS} \mathrm{m}^{-1}$, sodium absorption ratio $\left.(\mathrm{SAR})=27.73\left(\mathrm{mmol} \mathrm{l}^{-1}\right)^{1 / 2}\right\}$ was selected. The experimental design was randomized complete block design (RCBD) with three replications having plot size of $4 \mathrm{~m}$ x $6 \mathrm{~m}$. The cropping seasons were Kharif (June- Sep- tember) and Rabi (October-March). Cropping scheme used was as under:

Rabi crops were sown during the last week of November during 2010-11 and 2011-12 and Kharif crops were sown in last week of June during 2011 and 2012 in the same field. All cultural and management practices were carried out uniformly as and when required. Grain yield of each crop was recorded at maturity, whereas, for qulfa and podina biomass yield of economic value was noted. After harvesting of each crop, composite soil samples were collected for analysis of $\mathrm{pH}, \mathrm{EC}_{\mathrm{e}}$ and SAR. All the soil analysis was carried out following the method of U.S. Salinity Laboratory Staff (1954). In order to appraise the economic feasibility of different crop rotation total income was estimated by using existing price of each crop in local markets. Net income was derived subtracting the total expenses from total income and benefit: cost ratio (BCR) was computed by dividing gross income with total expenses (Shah et al., 2013). Collected data was subjected to analysis of variance following the method of Steel et al. (1997) to sort out significant differences among treatments at $5 \%$ probability level.

\section{RESULTS}

\subsection{RABI 2011-12}

Data in Table 1 revealed that during first Rabi season (2011-12) maximum yield was produced by wheat crop (2.04 and $1.93 \mathrm{tha}^{-1}$ ) in $\mathrm{T}_{1}$ and $\mathrm{T}_{2}$ respectively followed by ispagol with grain yield of 0.39 and $0.38 \mathrm{t} \mathrm{ha}^{-1}$ in $\mathrm{T}_{3}$ and $\mathrm{T}_{4}$ respectively. While minimum yield of $0.31 \mathrm{t} \mathrm{ha}^{-1}$ was recorded in ajwain. With respect to economic value maximum return of Rs. 55716 and $51618 \mathrm{ha}^{-1}$ was earned by wheat crop in $\mathrm{T}_{1}$ and $\mathrm{T}_{2}$ respectively which was statistically non-significant $(p<0.05)$ with economic value of ajwain (Rs. 49600). Minimum economic value was observed in ispagol with Rs. 36486 ha $^{-1}$.

\begin{tabular}{llll}
\hline Treatments & Crop rotation & Rabi crops & Kharif crops \\
\hline $\mathrm{T}_{1}$ & Wheat-Rice & Wheat (Triticum aestivum L.) & Rice (Oryza sativa L.) \\
$\mathrm{T}_{2}$ & Wheat-Sesamum & Wheat (Triticum aestivum L.) & Sesamum (Sesamum indicum L.) \\
$\mathrm{T}_{3}$ & Ispagol-Rice & Ispagol (Plantago ovata Forssk.) & Rice (Oryza sativa L.) \\
$\mathrm{T}_{4}$ & Ispagol-Qulfa & Ispagol (Plantago ovata Forssk.) & Qulfa (Portulaca oleracea L.) \\
$\mathrm{T}_{5}$ & Tukhum-e-blangoo-Qulfa & Tukhum-e-blangoo (Lallemantia royleana Benth. in Wall.) & Qulfa (Portulaca oleracea L.) \\
$\mathrm{T}_{6}$ & Ajwain-Niazboo & Ajwain (Carum copticum (L.) Link.) & Niazboo (Ocimum basilicum L.) \\
$\mathrm{T}_{7}$ & Saunf-Podina & Saunf (Foeniculum vulgare Mill.) & Podina (Mentha piperita L.) \\
\hline
\end{tabular}


Table 1: Yield and economic analysis of rabi crops 2011-12

\begin{tabular}{|c|c|c|c|c|}
\hline \multicolumn{2}{|c|}{ Treatments (Crop Rotation) } & \multirow{2}{*}{$\begin{array}{l}\text { Crop } \\
\text { Wheat }\end{array}$} & \multirow{2}{*}{$\frac{\text { Yield }\left(\mathrm{t} . \text { ha }^{-1}\right)}{1.93 \mathrm{~A}}$} & \multirow{2}{*}{$\begin{array}{l}\text { Economic Value (Rs.) } \\
51618 \mathrm{AB}\end{array}$} \\
\hline $\mathrm{T}_{1}$ & Wheat-rice & & & \\
\hline $\mathrm{T}_{2}$ & Wheat-sesamum & Wheat & $2.04 \mathrm{~A}$ & $55716 \mathrm{~A}$ \\
\hline $\mathrm{T}_{3}$ & Ispagol-rice & Ispagol & $0.39 \mathrm{~B}$ & $39778 \mathrm{CD}$ \\
\hline $\mathrm{T}_{4}$ & Ispagol-qulfa & Ispagol & $0.38 \mathrm{~B}$ & $36486 \mathrm{D}$ \\
\hline $\mathrm{T}_{5}$ & Tukhum-e-blangoo-qulfa & Tukhum-e-blangoo & $0.36 \mathrm{~B}$ & $41233 \mathrm{CD}$ \\
\hline $\mathrm{T}_{6}$ & Ajwain-niazboo & Ajwain & $0.31 \mathrm{~B}$ & $49600 \mathrm{AB}$ \\
\hline $\mathrm{T}_{7}$ & Saunf-podina & Saunf & $0.33 \mathrm{~B}$ & $45433 \mathrm{BC}$ \\
\hline
\end{tabular}

Means sharing the same letters are statistically similar at $p \leq 0.05$

\subsection{KHARIF 2012}

During Kharif season (2012) the highest yield of 2.32 and $2.24 \mathrm{t} \mathrm{ha}^{-1}$ was ensued by rice in $\mathrm{T}_{1}$ and $\mathrm{T}_{3}$ respectively followed by grain yield of $0.42 \mathrm{t} \mathrm{ha}^{-1}$ produced by niazbo which was statistically $(p<0.05)$ alike with yield of podina, qulfa and sesamum. As far as economic value of kharif crops was concerned maximum economic value (Rs. $71852 \mathrm{ha}^{-1}$ ) was observed in rice crop however it was statistically insignificant $(p<0.05)$ with qulfa and niazbo. Minimum economic value was recorded in sesamum (Rs. 37742 ha $^{-1}$ ).

\subsection{RABI 2012-13}

Data (Table 3) depicted that during $2^{\text {nd }}$ Rabi season maximum yield was produced by wheat crop. Wheat produces the yield of 2.21 and $1.99 \mathrm{t} \mathrm{ha}^{-1}$ in $\mathrm{T}_{2}$ and $\mathrm{T}_{1}$ respectively. Minimum yield was produced by ajwain $\left(0.32 \mathrm{t} \mathrm{ha}^{-1}\right)$ which was statistically $(p<0.05)$ non-significant with yield of ispagol and saunf. Data regarding the economic value showed that maximum economic value (Rs. $58049 \mathrm{ha}^{-1}$ ) was obtained by wheat crop followed by ajwain and both crops remain statistically $(p<0.05)$ non-

Table 2: Yield and economic analysis of Kharif crops 2012

\begin{tabular}{lllll}
\hline \multicolumn{2}{l}{ Treatments (Crop Rotation) } & Crop & Yield $\left(\mathrm{t} \mathrm{ha}^{-1}\right)$ & Economic Value $\left(\right.$ Rs. ha $\left.{ }^{-1}\right)$ \\
\hline $\mathrm{T}_{1}$ & Wheat-rice & Rice & $2.32 \mathrm{~A}$ & $71852 \mathrm{~A}$ \\
$\mathrm{~T}_{2}$ & Wheat-sesamum & Sesamum & $0.38 \mathrm{~B}$ & $37742 \mathrm{~B}$ \\
$\mathrm{~T}_{3}$ & Ispagol-rice & Rice & $2.24 \mathrm{~A}$ & $69481 \mathrm{~A}$ \\
$\mathrm{~T}_{4}$ & Ispagol-qulfa & Qulfa & $0.31 \mathrm{~B}$ & $69404 \mathrm{~A}$ \\
$\mathrm{~T}_{5}$ & Tukhum-e-blangoo-qulfa & Qulfa & $0.34 \mathrm{~B}$ & $68455 \mathrm{~A}$ \\
$\mathrm{~T}_{6}$ & Ajwain-niazboo & Niazboo & $0.42 \mathrm{~B}$ & $66868 \mathrm{~A}$ \\
$\mathrm{~T}_{7}$ & Saunf-podina & Podina & $0.35 \mathrm{~B}$ & $49519 \mathrm{~B}$ \\
\hline
\end{tabular}

Means sharing the same letters are statistically similar at $p \leq 0.05$

Table 3: Yield and economic analysis of Rabi crops 2012-13

\begin{tabular}{|c|c|c|c|c|}
\hline \multicolumn{2}{|c|}{ Treatments (Crop Rotation) } & \multirow{2}{*}{$\begin{array}{l}\text { Crop } \\
\text { Wheat }\end{array}$} & \multirow{2}{*}{$\begin{array}{l}\text { Yield }\left(\mathrm{t} \mathrm{ha}^{-1}\right) \\
1.99 \mathrm{~B}\end{array}$} & \multirow{2}{*}{$\begin{array}{l}\left.\text { Economic Value (Rs. ha }{ }^{-1}\right) \\
52285 \text { B }\end{array}$} \\
\hline $\mathrm{T}_{1}$ & Wheat-rice & & & \\
\hline $\mathrm{T}_{2}$ & Wheat-sesamum & Wheat & $2.21 \mathrm{~A}$ & 58049 A \\
\hline $\mathrm{T}_{3}$ & Ispagol-rice & Ispagol & $0.42 \mathrm{C}$ & $42445 \mathrm{C}$ \\
\hline $\mathrm{T}_{4}$ & Ispagol-qulfa & Ispagol & $0.40 \mathrm{C}$ & $40153 \mathrm{C}$ \\
\hline $\mathrm{T}_{5}$ & Tukhum-e-blangoo-qulfa & Tukhum-e-blangoo & $0.37 \mathrm{C}$ & $45900 \mathrm{C}$ \\
\hline $\mathrm{T}_{6}$ & Ajwain-niazboo & Ajwain & $0.32 \mathrm{C}$ & 52267 B \\
\hline $\mathrm{T}_{7}$ & Saunf-podina & Saunf & $0.34 \mathrm{C}$ & $54767 \mathrm{AB}$ \\
\hline
\end{tabular}

Means sharing the same letters are statistically similar at $p \leq 0.05$ 
Table 4: Yield and economic analysis of Kharif crops 2013

\begin{tabular}{lllll}
\hline \multicolumn{2}{c}{ Treatments (Crop Rotation) } & Crop & Yield $\left(\mathrm{t} \mathrm{ha}^{-1}\right)$ & Economic Value $\left(\right.$ Rs. ha $\left.{ }^{-1}\right)$ \\
\hline $\mathrm{T}_{1}$ & Wheat-rice & Rice & $2.08 \mathrm{~A}$ & $88542 \mathrm{~A}$ \\
$\mathrm{~T}_{2}$ & Wheat-sesamum & Sesamum & $0.25 \mathrm{C}$ & $37500 \mathrm{C}$ \\
$\mathrm{T}_{3}$ & Ispagol-rice & Rice & $1.98 \mathrm{~A}$ & $84292 \mathrm{~A}$ \\
$\mathrm{~T}_{4}$ & Ispagol-qulfa & Qulfa & $0.61 \mathrm{~B}$ & $73833 \mathrm{AB}$ \\
$\mathrm{T}_{5}$ & Tukhum-e-blangoo-qulfa & Qulfa & $0.66 \mathrm{~B}$ & $79833 \mathrm{~A}$ \\
$\mathrm{~T}_{6}$ & Ajwain-niazboo & Niazboo & $0.53 \mathrm{~B}$ & $61333 \mathrm{~B}$ \\
$\mathrm{~T}_{7}$ & Saunf-podina & Podina & $0.30 \mathrm{C}$ & $36120 \mathrm{C}$ \\
\hline
\end{tabular}

Means sharing the same letters are statistically similar at $p \leq 0.05$

significant from each other. While minimum economic value (Rs. $40153 \mathrm{ha}^{-1}$ ) was showed by ispagol.

\subsection{KHARIF 2013}

Data in table 4 displayed that during $2^{\text {nd }}$ Kharif season maximum yield of 2.08 and $1.98 \mathrm{tha}^{-1}$ was produced by rice crop in $T_{1}$ and $T_{3}$ respectively followed by qulfa crop, while minimum yield $\left(0.25 \mathrm{t} \mathrm{ha}^{-1}\right)$ was recorded in sesamum. Economic value data showed that maximum economic return of Rs. 88542 ha $^{-1}$ was achieved by rice crop followed by qulfa crop, however, difference between to crop was not large enough to reach a level of significance $(p<0.05)$. Minimum economic value (Rs. $\left.36120 \mathrm{ha}^{-1}\right)$ was observed in podina crop.

\subsection{SOIL PROPERTIES}

Soil analysis data (Table 5) at the end of study showed that soil properties were also considerably affected by type of crop used in crop rotation. Among all the rotation ricewheat crop rotation showed a minimum value (8.36) for soil $\mathrm{pH}$ followed by ispagol-rice rotation with $\mathrm{pH}$ value of
8.39. Maximum $\mathrm{pH}$ value (8.44) was noted in tukhum-eblangoo-qulfa rotation. Similarly, rice crop also improved the salinity indicators i.e $\mathrm{EC}_{\mathrm{e}}$ and SAR of soil. Minimum value of $\mathrm{EC}_{\mathrm{e}}\left(3.87 \mathrm{dS} \mathrm{m}^{-1}\right)$ and SAR $\left(20.96 \mathrm{mmol} \mathrm{l}^{-1}\right)^{1 / 2}$ were noted in rice wheat crop rotation. Whereas, maximum value $\left(4.50 \mathrm{dS} \mathrm{m}^{-1}\right)$ of $\mathrm{EC}_{\mathrm{e}}$ was observed in saunfpodina rotation and for SAR maximum value (24.80) was observed where ajwain-niazboo rotation was used.

\subsection{ECONOMIC ANALYSIS}

Economic analysis data (Table 6) at the end of 2 years study showed that different crop rotation in salt affected soils had significant effect on gross income, net income and benefit: cost ratio (BCR). Maximum net income (208352 Rs. ha ${ }^{-1}$ ) and BCR (4.72) was recorded by rice-wheat crop rotation and minimum net income (128207 Rs. ha ${ }^{-1}$ ) and BCR (3.10) was observed in wheat sesamum rotation.

\section{DISCUSSION}

Decision of suitable crop rotation scheme in salt af-

Table 5: Effect of different crop rotation on soil chemical properties at the end of experiment

\begin{tabular}{|c|c|c|c|c|c|c|c|}
\hline \multicolumn{2}{|c|}{$\begin{array}{l}\text { Treatments } \\
\text { (Crop Rotation) }\end{array}$} & \multirow{2}{*}{$\frac{\mathrm{pH}_{\mathrm{s}}}{8.36}$} & \multirow{2}{*}{$\begin{array}{l}\text { \% decrese over } \\
\text { initial value }\end{array}$} & \multirow{2}{*}{$\begin{array}{l}\begin{array}{l}\mathrm{EC}_{\mathrm{e}} \\
\left(\mathrm{dS} \mathrm{m}^{-1}\right)\end{array} \\
3.87\end{array}$} & \multirow{2}{*}{$\begin{array}{l}\text { \% decrese over } \\
\text { initial value } \\
25.57\end{array}$} & \multirow{2}{*}{$\begin{array}{l}\text { SAR } \\
\left(\mathrm{mmol} \mathrm{l}^{-1}\right)^{1 / 2} \\
20.96\end{array}$} & \multirow{2}{*}{$\begin{array}{l}\% \text { decrese } \\
\text { over initial } \\
\text { value }\end{array}$} \\
\hline $\mathrm{T}_{1}$ & Wheat-rice & & & & & & \\
\hline $\mathrm{T}_{2}$ & Wheat-sesamum & 8.40 & 2.89 & 4.32 & 16.92 & 22.4 & 19.22 \\
\hline $\mathrm{T}_{3}$ & Ispagol-rice & 8.39 & 3.00 & 3.92 & 24.61 & 21.76 & 21.52 \\
\hline $\mathrm{T}_{4}$ & Ispagol-qulfa & 8.43 & 2.54 & 4.46 & 14.23 & 23.8 & 14.17 \\
\hline $\mathrm{T}_{5}$ & Tukhum-e-blangoo-qulfa & 8.44 & 2.42 & 4.44 & 14.61 & 24.12 & 13.01 \\
\hline $\mathrm{T}_{6}$ & Ajwain-niazboo & 8.41 & 2.77 & 4.38 & 15.76 & 24.80 & 10.56 \\
\hline $\mathrm{T}_{7}$ & Saunf-podina & 8.42 & 2.65 & 4.50 & 13.46 & 23.36 & 15.75 \\
\hline
\end{tabular}


Table 6: Effect of different crop rotation on net income and benefit: cost ratio (BCR) at the end of study

\begin{tabular}{|c|c|c|c|c|c|}
\hline \multicolumn{2}{|c|}{$\begin{array}{l}\text { Treatments } \\
\text { (Crop Rotation) }\end{array}$} & \multirow{2}{*}{ 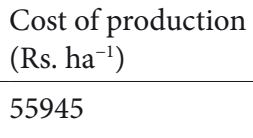 } & \multirow{2}{*}{$\begin{array}{l}\text { Gross income } \\
\left(\text { Rs. }^{-1}\right)\end{array}$} & \multirow{2}{*}{$\begin{array}{l}\text { Net income } \\
\left(\text { Rs. ha }^{-1}\right)\end{array}$} & \multirow{2}{*}{$\begin{array}{l}\text { Benefit: costra- } \\
\text { tio (BCR) } \\
4.72\end{array}$} \\
\hline $\mathrm{T}_{1}$ & Wheat-rice & & & & \\
\hline $\mathrm{T}_{2}$ & Wheat-sesamum & 60800 & 189007 & 128207 & 3.10 \\
\hline $\mathrm{T}_{3}$ & Ispagol-rice & 61356 & 235995 & 174639 & 3.84 \\
\hline $\mathrm{T}_{4}$ & Ispagol-qulfa & 55987 & 219876 & 163889 & 3.92 \\
\hline $\mathrm{T}_{5}$ & Tukhum-e-blangoo-qulfa & 65344 & 235421 & 170077 & 3.60 \\
\hline $\mathrm{T}_{6}$ & Ajwain-niazboo & 58650 & 230068 & 171418 & 3.92 \\
\hline $\mathrm{T}_{7}$ & Saunf-podina & 55182 & 185839 & 130657 & 3.36 \\
\hline
\end{tabular}

fected soil is very complex intrinsically region dependent task and should be based on salinity tolerance, economic value of the crop, impact on environment, generated revenue, available resources, food security and market conditions (Dogliotti et al., 2014 ; Smajgl et al., 2016). Crop rotation scheme on a farm is justified by preserving soil quality (Brankatschk and Finkbeiner, 2015; Nemecek et al., 2015), increased economic benefits (Dhuyvetter et al., 1996) improved soil properties (Peterson and Westfall, 2004), environmental perspective (Reckling et al., 2015), ensuring long term yield and soil fertility (Hennessy, 2006; Dury et al., 2011). Different crop rotation models have been evaluated in terms of agronomic as well as farm profitability in combination with their impact on soil health (Hulugalle et al., 2002; Popp et al., 2005).

Crop diversification in a cropping sequence generally reduces risk of failure through more stable yield and market price diversification as low income by one crop can be offset by high income of another crop in a given year (Meyer-Aurich et al., 2006; Nemecek et al., 2008). Zentner et al. (2002a) also reported that farmers who adopted diversified crop rotation earned more income.

Therefore, in this study we proposed the seven crop rotations for salt affected soil which should be acceptable to local farmers, can generate the income and contribute to food security and rural development. In developing countries one of most common factor for fast adoptability of a cropping sequence by farming community is expected market price and resulting net economic return of selected crop (Hurine et al., 2000; Salassi et al., 2013).

Nevertheless, viability and adoptability of cropping system does not depend on crop yield but also on efficiency in use of available resources (Moreno et al., 2011). Net return generated by a rotation is very critical because selection of a suitable crop affects the affects economic benefits (Jatoe et al., 2008; Martin and Hanks, 2009). In general, farmers tend to pursue activities which maximizes their farm profitability, reduced physical labor and financial risk, and are convenient and enjoyable (Bowman and Zilberman, 2013).
Salt stress rapidly reduces the plant growth due to osmotic stress and ion toxicity (accumulation of toxic $\mathrm{Cl}^{-}$ and $\mathrm{Na}^{+}$in cells of shoot) and ultimately the final yield of crops (Munns and Tester, 2008; Tamimi et al., 2016). The ability of a plant to tolerate salinity is a vital factor in plant productivity (Momayezi et al, 2009). Considering individual year yields, wheat was the most high yielding crop in Rabi season, while rice perform better among Kharif crops. These crops tolerate the salinity mainly two mechanisms, osmotic tolerance and ion exclusion (Munns and Tester, 2008; Roy et al, 2014) while, yield of other crops was low due to higher salinity sodicity problem and inefficient tolerant mechanisms. Also, ricewheat rotation showed a preventive impact on soil salinity/sodicity build up and consequently crop yield was increased. Rice and wheat crop are previously reported as salt tolerant and can utilize to maximize the productivity and profitability of salt affected soils.

Economic circumstances of developing countries are compelling farmers to cultivate crops that generate high income, leading to cereal-dominated crop rotations (Sieling \& Christen, 2015).

Economic performance of a crop rotation contributes to its adaptation and continuity but in general economic analysis studies of rotations are scarce (González et al., 2002). Many researchers study the economic performance of different crop rotations (Chen, 2009; Chen and Chen, 2011; Zhu et al., 2011).

Rice-wheat rotation is a popular crop rotation in southern and eastern Asia with an area of 24 to 27 million hectares (Wassmann et al., 2004). According to economic analysis of present study, rice wheat cropping scheme exhibited more benefit per hectare of crop and this rotation may provide maximum economic benefit to farmers in comparison to other. One of the plausible explanation for yield and revenue advantage of rice and wheat crops under salt affected soil might be their more salinity tolerance in comparison with other crops used in rotation (Yeo et al, 1990; Purushottam et al., 2012; Saringi et al., 2015; Hasan et al., 2015) coupled with market 
value and commercialization of these crops (Singh et al., 2014). More revenue generated by rice wheat crop rotation may be due to prevailing socio-economic conditions of the region (Livingston et al., 2012; Pare et al., 2015; Liu et al., 2016) as both crops are used as staple commodities and their market prices were less variable as compared to other crops in rotation. So adequate and high quality yield of rice and wheat with substantial net return contributes the rice- wheat rotation dominating all other rotations. According to González et al. (2013) wheat earned the income of US\$1051 ha ${ }^{-1}$ and barley US $\$ 711 \mathrm{ha}^{-1}$, which are economically attractive and more than bean and sugar beet. Comparable results have been reported by Mellado et al. (2000), Stanger et al. (2008), and Hirzel (2011). Dominant and profitable crop rotations with reduced risk depend on prevailing conditions of specific regions (DeVuyst and Halvorson, 2004; Saharawat et al., 2010). Sánchez-Girón et al. (2004) also evaluated the economic performance of different crop rotations wheat-barley, wheat-vetch and barley-vetch for sixteen years and concluded that economic return of crop rotation depend upon the factors beyond control like market price and climate of the region that influence the variable like cost of production, quality and quantity of yield, and net income which are the main sources of variability or economic uncertainty. In a long term study of fifteen years Stanger et al. (2006) evaluated the effect of different nitrogen levels on seven crop rotation i.e. continuous alfalfa (Medicago sativa L.) (AA), corn-soybean-corn-oat with alfalfa seeding-alfalfa (CSCOaA), continuous corn (Zea mays L.) (CC), corn-alfalfa (CA), corn-corn-oat (Avena sativa L.) with alfalfa seeding-alfalfa-alfalfa (CCOaAA), corn-corn-corn-alfalfa-alfalfa (CCCAA) and corn-soybean (Glycine max (L.) Merr.) (CS). They reported that maximum return was earned by corn-soybean rotation at all nitrogen levels. Similarly Singh et al. (2011) study the productivity and economic performance of different crop rotation like rice-potato-green gram, rice-pea, rice-wheat, rice-wheat-sesbania, rice-lentil + mustard -cowpea, rice-chickpea, rice-lentil-cowpea, rice-maize + pea - cowpea, rice-mustard-green gram and ricewheat-green gram. They concluded that rice-potatogreen gram cropping system gave the highest productivity net return and benefit: cost ratio.

Similar findings were reported by Kaur et al. (2007) that paddy-based crop rotations were beneficial for salt affected soil and they also recommended the fallow-wheat cropping sequence as an alternative cropping scheme. In similar studies, the highest net income was obtained from wheat-rice rotations (Guan et al., 2011; Zentner et al., 2002), the rice-potato-sunflower sequence (Jaiswal et al., 1993) and rapeseed-common vetch + sunflower-wheat (Dogan et al., 2008). Our results are reinforced by earlier findings that not only the sequence, but also the choice of crops in the rotation influences the economic margin (Wilson et al., 2003; Jatoe et al., 2008). Economic benefits of different crop rotation have been reported by several researchers ( $\mathrm{Tz}$ ilivakis et al. 2005; Chen et al., 2015; Babulicova, 2016; Aminifar et al., 2017) which are in agreement with our findings.

\subsection{SOIL PROPERTIES}

Hence along with direct income generated, long term environmental impacts and sustainability of a cropping sequence must be also taken into account when determining its suitability for salt affected soil. Rotation type had substantial effects on soil health and qualities, results showed that all cropping sequences lowered the soil $\mathrm{pH}, \mathrm{EC}_{\mathrm{e}}$ and SAR at the end of study. Rice-wheat rotation showed maximum reduction of $3.35 \%$ in soil $\mathrm{pH}$, which may be ascribed to leaching of soluble salts and $\mathrm{CaCO}_{3}$ resulting a rapid fall in $\mathrm{pH}$ value (Cui et al., 2012; Fu et al., 2014; Neugschwandtner et al., 2014; Mahmood et al., 2016). Results of this study are in agreement with finding of Abro and Mahar (2007) who found a significant decrease in salinity indicators i.e. $\mathrm{pH}, \mathrm{EC}_{\mathrm{e}}$ and $\mathrm{SAR}$ after the rice harvest, however, a slight increase in $\mathrm{pH}$ and $\mathrm{EC}_{\mathrm{e}}$ were recorded while, the SAR levels decreased further after wheat harvest. Similarly, Gehad (2003) also reported rice wheat rotation as most suitable cropping pattern during reclamation of salt affected soil. Data also showed that rice wheat cropping pattern reduces $\mathrm{EC}_{\mathrm{e}}$ and SAR upto 25.57 and $24.41 \%$ respectively, which could be explained due to leaching effect of irrigation as rice crop required the frequent irrigation (Iost et al., 2007; Fu et al., 2012). Our results are supported by series of findings that cropping pattern revealed an absolute temporal trend on soil properties (Fu et al., 2014; Lazicki et al., 2016; King and Hofmockel, 2017). Similar findings were reported by Fu et al. (2012) and Liu et al. (2013) that the rice-barley cropping sequence decreased soil salinity after a reclamation time of more than 10 years. Furthermore, cultivation of rice favored the addition of soil organic matter and decreases the $\mathrm{Na}, \mathrm{Ca}$ and $\mathrm{Mg}$ contents (Chen et al., 2011; Zhang and He, 2004) which tends to converge soil $\mathrm{pH}$ to neutral and improved the soil properties (Zou et al., 2011). In study conducted by $\mathrm{Fu}$ et al. (2014) they found that rice-barley crop rotation had more ameliorative effect on soil properties and significantly decreased the $\mathrm{pH}$ value than cotton-barley crop rotation system at the same year. 


\section{CONCLUSION}

Utilization and remediation of marginally salt affected soil is a global challenge for sustainable agriculture. Optimizing the agricultural production from salt affected soil requires appropriate farmer's decision based on economic and environmental constraints. Finally results generated by current study suggested that ricewheat crop rotation is the most suitable and economically attractive cropping scheme in salt affected soil which has potential to provide better long-term income to farmers, improve soil health and combat soil deterioration caused by salinity.

\section{REFERENCES}

Abro, S.A., Mahar, A.R. (2007). Reclamation of saline-sodic soils under rice-wheat crop rotation. Pakistan Journal of Botany, 39(7), 2595-2600.

Aminifar, J., Ramroudi, M., Galavi, M. and Mohsenabadi, G. (2017). Productivity and economic efficiency of wheat in rotation with cotton. Iran Agricultural Research, 36(2), 5560.

Babulicova, M. (2016). Enhancing of winter wheat productivity by the introduction of field pea into crop rotation. Agriculture, 62(3), 101-110. https://doi.org/10.1515/agri-20160011

Bhatti, U.A., Khan, M.M. (2012). Review Soil management in mitigating the adverse effects of climate change. Soil and Environment, 31(1), 1-10.

Bowman, M.S., Zilberman, D. (2013). Economic Factors Affecting Diversified Farming Systems. Ecology and Society, 18(1), 33-48. https://doi.org/10.5751/ES-05574-180133

Brady, N.C., Well, R.R. (2008). The nature and properties of soils. Pearson-Prentice Hall, Upper Saddle River NJ p 990.

Brankatschk, G., Finkbeiner, M. (2015). Modeling crop rotation in agricultural LCAs challenges and potential solutions. Agricultural Systems, 138, 66-76. https://doi.org/10.1016/j. agsy.2015.05.008

Bremer, E., Janzen, H.H., Ellert, B.H., McKenzie, R.H. (2008). Soil organic carbon after twelve years of various crop rotations in an Aridic Boroll. Soil Science Society of America Journal, 72, 970-974. https://doi.org/10.2136/sssaj2007.0327

Chen, C., Anton B., Reza, K., Afshara, Karnes, N. (2015). Intensification of dryland cropping systems for bio-feedstockproduction: Evaluation of agronomic and economic benefits of Camelina sativa. Industrial Crops and Products, 71, 114-121. https://doi.org/10.1016/j.indcrop.2015.02.065

Chen, L.M., Zhang, G.L., Effland, W.R. (2011). Soil characteristic response times and pedogenic thresholds during the 1000-year evolution of a paddy soil chronosequence. Soil Science Society of America Journal, 75, 1-14. https://doi. org/10.2136/sssaj2011.0006

Chen, Q.G. (2009). Research on the effect of input on yield and economic benefits of super rice: Based on the investigation of the 568 households which be-longed to ten counties in two southward provinces and one northward province. Chinese Journal of Agrometeorology, 30, 295-300.

Chen, Q.G., and Chen, Y.Z. (2011). Comparison of economical benefits between super rice and conventional rice in different regions: Based on an Investigation of 413 farm households in Zhejiang and Hunan provinces. Hybrid Rice, 26(3), 61-67.

Cui, J., Liu, C., Li, Z.L., Wang, L., Chen, X.F., Ye, Z.Z., Fang, C.M. (2012). Long-term changes in topsoil chemical properties under centuries of cultivation after reclamation of coastal wetlands in the Yangtze Estuary, China. Soil and Tillage Research, 123, 50-60. https://doi.org/10.1016/j. still.2012.03.009

Dagar, J.C. (1995). Characteristics of halophytic vegetation in India. In: Khan, M.A. and Ungar, I.A. pp. 255-276. Biology of Salt Tolerant Plants. (Eds.), University of Karachi, Karachi. 476 pp.

Dhuyvetter, K.C., Thompson, C.R., Norwood, C.A., Halvorson, A.D. (1996). Economicsof dryland cropping systems in the Great Plains: a review. Journal of Production Agriculture, 9, 216-222. https://doi.org/10.2134/jpa1996.0216

Dhuyvetter, K.C., Thompson, C.R., Norwood, C.A., Halvorson, A.D. (1996). Economic of dry land cropping system in the Great Plains. Journal of Production Agriculture, 9, 216-222. https://doi.org/10.2134/jpa1996.0216

Dogan, R., Goksoy. T. A., Yagdi, K. and Turan, M.Z. (2008). Comparison of the effects of different crop rotation systems on winter wheat and sunflower under rain-fed conditions. African Journal of Biotechnology, 7(22), 4076-4082.

Dogliotti, S., Rodriguez, D., Lopez-Ridaura, S., Tittonell, P., Rossing, W. (2014). Designing sustainable agricultural production systems for a changing world: methods and applications. Agricultural Systems, 126, 1-2. https://doi. org/10.1016/j.agsy.2014.02.003

Dury, J., Bergez, J.E., Schaller, N., Garcia, F., Reynaud, A. (2011). Models to support cropping plan and crop rotation decisions. A review. Agronomy for Sustainable Development, 32 (2), 567-580. https://doi.org/10.1007/s13593-011-0037-X

Fu, Q. Nengfei, D., Chen L., Yicheng, L., Bin, G. (2014). Soil development under different cropping systems in a reclaimed coastal soil chronosequence. Geoderma, 230, 50-57. https:// doi.org/10.1016/j.geoderma.2014.03.026

Fu, Q.L., Liu, C., Ding, N.F., Lin, Y.C., Guo, B., Luo, J.F., Wang, H.L. (2012). Soil microbial communities and enzyme activities in a reclaimed coastal soil chronosequence under rice-barley cropping. Journal of Soils and Sediments, 12, 1134-1144. https://doi.org/10.1007/s11368-012-0544-7

Gehad, A. (2003). Deteriorated soils in Egypt: management and rehabilitation-report; executive authority for land improvement project (EALIP). Ministry of Agriculture and Land Reclamation, Cairo.

Gnanamanickam, S.S. (2009). Rice and its importance to human life. Progress in Biological Control, 8, 1-11. https://doi. org/10.1007/978-90-481-2465-7_1

Gonzalez U., Pablo, U., Juan, H., Ingrid, M.G. (2013). Economic evaluation of a crop rotation portfolio for irrigated farms in central Chile. Chilean Journal of Agricultural Re- 
search, 73(3), 243-249. https://doi.org/10.4067/S0718 58392013000300006

González, J., Francisco, E., Foster, W. (2002). Selección de portfolios de rotaciones culturales económicamente óptimos para la Precordillera Andina de la VIII Región. Agricultura Técnica, 62, 583-595. https://doi.org/10.4067/S036528072002000400010

Goplen, J.J., Jeffrey, A.C., Craig, C.S., Roger, L.B., Fritz, R. B., Lisa M. B., and Jeffrey, L. G. (2018). Economic Performance of Crop Rotations in the Presence of Herbicide-Resistant Giant Ragweed. Agronomy Journal, 110(1), 260-268. https://doi.org/10.2134/agronj2016.09.0536

Guan, G., Tu, S., Yang, J., Zhang, J., Yang, L. (2011). A field study on effects of nitrogen fertilization modes on nutrient uptake, crop yield and soil biological properties in rice-wheat rotation system. Agricultural Sciences in China, 10, 12541261. https://doi.org/10.1016/S1671-2927(11)60117-X

Hasan, A., Hafiz, R.H., Nurealam S., Khatun, M., Rabiul, I., Abdullah, A.M. (2015). Evaluation of Wheat Genotypes for Salt Tolerance Based on Some Physiological Traits. Journal of Crop Science and Biotechnology, 18(5), 333-340. https:// doi.org/10.1007/s12892-015-0064-2

Hennessy, D.A. (2006). On monoculture and the structure of crop rotations. American Journal of Agricultural Economics, 88, 900-914. https://doi.org/10.1111/j.14678276.2006.00905.x

Hirzel, J. (2011). Fertilización de cultivos en Chile. Instituto de Investigaciones Agropecuarias INIA, Centro Regional de Investigación Quilamapu, Chillán, Chile.

Huirne, R.B.M., Meuwissen, M.P.M., Hardaker, J.B., Anderson, J.R. (2000). Risk and risk management in agriculture: an overview and empirical results. International Journal of Risk Assessment and Management, 1, 125-136. https://doi. org/10.1504/IJRAM.2000.001491

Huirne, R.B.M., Meuwissen, M.P.M., Hardaker, J.B., Anderson, J.R. (2000). Risk and risk management in agriculture: an overview and empirical results. International Journal of Risk Assessment and Management, 1, 125-136. https://doi. org/10.1504/IJRAM.2000.001491

Hulugalle, N.R., Entwistle, P.C., Weaver, T.B., Scott, F., Finlay, L.A. (2002). Cotton- based rotation systems on asodic vertosol under irrigation: effects on soil quality and profitability. Australian Journal of Experimental Agriculture, 42(3), 379-387. https://doi.org/10.1071/EA00118

Iost, S., Landgraf, D., Makeschin, F. (2007). Chemical soil properties of reclaimed marsh soil from Zhejiang Province P.R. China. Geoderma, 142, 245-250. https://doi.org/10.1016/j. geoderma.2007.08.001

Jaiswal, V.P., Singh, J.P., Karamjit, S., Shekhawat, G.S., Khuran, S.M.P., Pandey, S.K., Chandla, V.K. (1993). Production potential and profitability of some potato based cropping sequences in north-western plains. Potato: present and future. Proceedings of the National Symposium held at Modipuram. pp. 101-105.

Jat, R.A., Dungrani, R.A., Arvadia, M.K. and Kanwar L.S. (2012). Diversification of rice (Oryza sativa L.) based cropping systems for higher productivity, resource-use efficiency and economic returns in south Gujarat, India. Archives of Agronomy and Soil Science, 58(6), 561-57. https://doi.org /10.1080/03650340.2010.533172

Jatoe, J., Yiridoe, E., Weersink, A., Clark, S. (2008). Economic and environmental impacts of introducing land use policies and rotations on Prince Edwards Island potato farms. Land Use Policy 25, 309-319. https://doi.org/10.1016/j.landusepol.2007.08.005

Jinni, D., Joseph, B. (2017). Physiological mechanism of salicylic acid for alleviation of salt stress in rice. Rice Science, 24(2), 97-108. https://doi.org/10.1016/j.rsci.2016.07.007

Karlen, D.L., Varvel, G.E., Bullock, D.G., Cruse, R.M. (1994). Crop rotations for the 21st century. Advance in Agronomy, 53, 1-44. https://doi.org/10.1016/S0065-2113(08)60611-2

Kaur R, Malik, R., Paul, M. (2007). Long-term effects of various crop rotations for managing salt-affected soils through a field scale decision support system-a case study. Soil Use and Management, 23, 52-62. https://doi.org/10.1111/ j.1475-2743.2006.00055.x

Kaye, N.M., Mason, S.C., Jackson, D.S., Galusha, T.D. (2007). Crop rotation and soil amendments alters sorghum grain quality. Crop Science, 47, 722-729. https://doi.org/10.2135/ cropsci2006.05.0346

Kishk, M.A. (2000). Sustainable land use in poor countries and poor communities: a mirage of real water. In: Soil and sustainable agriculture in the new century. Egyptian Soil Science Society (ESSS)-Golden Jubilee Congress 1950-2000, Cairo. (Oct 23-25).

Knowler, D., Bradshaw, B. (2007). Farmers' adoption of conservation agriculture: a review and synthesis of recent research. Food Policy, 32, 25-48. https://doi.org/10.1016/j. foodpol.2006.01.003

Lacerda, C.F., Sousa, G.G., Silva, F.L.B., Guimaraes, F.V.A., Silva, G.L., Cavalcante, L.F. (2011). Soil salinization and maize and cowpea yield in the crop rotation system using saline waters. Engenharia Agricola, 31, 663-675. https://doi. org/10.1590/S0100-69162011000400005

Liu, C., Xu, J.M., Ding, N.F., Fu, Q.L., Guo, B., Lin, Y.C., Li, H., Li, N.Y. (2013). The effect of long term reclamation on enzyme activities and microbial community structure of saline soil at Shangyu, China. Environmental Earth Sciences, 69, 151-159. https://doi.org/10.1007/s12665-012-1943-1

Liu, X., Heikki, L., Tuomo, P., Yulia, P., Reimund, R., Taru, P. (2016). Dynamic economic modelling of crop rotations with farm management practices under future pest pressure. Agricultural Systems, 144, 65-76. https://doi. org/10.1016/j.agsy.2015.12.003

Livingston, M., Roberts, M.J., Zhang, Y. (2012). Optimal sequential plantings of corn and soybeans underprice uncertainty. North Carolina State University, Working paper.

Ma, H., Chong, K., Deng. X.W. (2007). Rice research: Past, present and future. Journal of Integrative Plant Biology, 49, 729730. https://doi.org/10.1111/j.1744-7909.2007.00515.x

Mahmoud, A., Ouda, S., Abd El-Hafez, S. (2016). High water consuming crops under control: I. Case of rice crop. In: Major crops and water scarcity in Egypt. Springer Publishing House, pp 69-82. https://doi.org/10.1007/978-3-31921771-0_5

Mellado, M., Madariaga, R. and Granger, D. (2000). Opala-INIA, a new spring bread wheat cultivar for the South Central 
area of Chile. Agricultura Técnica, 60, 415-418. https://doi. org/10.4067/S0365-28072000000400009

Meyer-Aurich, A., K. Janovicek, W. Deen, and A. Weersink. (2006). Impact of tillage and rotation on yield and economic performance in corn based cropping systems. Agronomy Journal, 98, 1204-1212. https://doi.org/10.2134/ agronj2005.0262

Momayezi, M.R., Zaharah, A.R., Hanafi, M.M., Mohd, R. (2009). Agronomic characteristics and proline accumulation of Iranian rice genotypes at early seedling stage under sodium salts stress. Malaysian Journal of Soil Science, 13, 59-75.

Munns, R., Tester, M. (2008). Mechanisms of salinity tolerance. Annual Review of Plant Biology, 59, 651-681. https://doi. org/10.1146/annurev.arplant.59.032607.092911

Nel, A.A., Loubser, H.L. (2004). The impact of crop rotation on profitability and production risk in the Eastern and North Western Free State. Agrekon, 43(1), 101-111. https://doi.org /10.1080/03031853.2004.9523638

Nemecek, T., Hayer, F., Bonnin, E., Carrou'ee, B., Schneider, A., Vivier, C. (2015). Designing eco-efficient crop rotations using life cycle assessment of crop combinations. European Journal of Agronomy, 65, 40-51. https://doi.org/10.1016/j. eja.2015.01.005

Nemecek, T., Richthofen, J.v., Dubois, G., Casta, P., Charles, R. and Pahl, H. (2008). Environmental impacts of introducing grain legumes into European crop rotations. European Journal of Agronomy 28, 380-393. https://doi.org/10.1016/j. eja.2007.11.004

Neugschwandtner, R.W., Liebhard, P., Kaul, H.P., Wagentristl, H. (2014). Soil chemical properties as affected by tillage and crop rotation in a long-term field experiment. Plant Soil Environment, 60(2), 57-62. https://doi. org/10.17221/879/2013-PSE

Ouda, S. A.H., Abd El-Hafeez, Z., Hamdy, K. (2016). Combating Deterioration in Salt-Affected Soil in Egypt by Crop Rotations. SpringerLink. https://doi.org/10.1007/978-3-31933660-2_6

Pare, M.C., Jean, L., Denis, P. (2015). Best management practices in Northern agriculture: A twelve-year rotation and soil tillage study in Saguenay-Lac-Saint-Jean. Soil and Tillage Research, 150, 83-92. https://doi.org/10.1016/j. still.2015.01.012

Peterson, G.A., Westfall, D.G. (2004). Managing precipitation use in sustainable dry land agro ecosystems. Annals of Applied Biology, 144, 127-138. https://doi. org/10.1111/j.1744-7348.2004.tb00326.x

Popp, M., Manning, P., Counce, P., Keisling, T. (2005). Ricesoybean rotations: opportunities for enhancing whole farm profits or water savings. Agricultural System, 86, 223-238. https://doi.org/10.1016/j.agsy.2004.09.008

Purushottam, K., Singh, D.K., Bharadwaj, A.K. (2012). Onfarm Evaluation of Agronomic Management Practices under Rice-wheat Cropping System. Extended Summaries. Third International Agronomy Congress, New Delhi, pp.1295-1296.

Rajarm, S., Braun, H. S. (2006). Wheat yield potential. Farm policy Journal, 3(1), 103-107.

Reckling, M., Hecker, J.M., Bergkvist, G., Watson, C. A., Zander,
P., Schlafke, N., Stoddard, F. L., Eory, V., Topp, C. F., Maire, J. (2015). A cropping system assessment framework evaluating effects of introducing legumes into crop rotations. European Journal of Agronomy, 76, 186-197. https://doi. org/10.1016/j.eja.2015.11.005

Robertson, G.P., Swinton, S.M. (2005). Reconciling agricultural productivity and environmental integrity: A grand challenge for agriculture. Frontiers in Ecology and the Environment. 3, 38-46. https://doi.org/10.1890/15409295(2005)003[0038:RAPAEI]2.0.CO;2

Roy, S.J., Negrao, S., Tester, M. (2014). Salt resistant crop plants. Current Opinion in Biotechnology, 26, 115-124. https://doi. org/10.1016/j.copbio.2013.12.004

Saharawat, Y.S., Singh, B., Malik, R.K., Ladha, J.K., Gathala, M., Jat, M.L. and Kumar, V. (2010). Evaluation of alternative tillage and crop establishment methods in a rice-wheat rotation in North Western IGP. Field Crops Research 116, 260-267. https://doi.org/10.1016/j.fcr.2010.01.003

Salassi , M.E., Michael, A. D., Kurt M. G. (2013). Economically optimal crop sequences using risk-adjusted network flows: Modeling cotton crop rotations in the southeastern United States. Agricultural Systems, 118, 33-40. https://doi. org/10.1016/j.agsy.2013.02.006

Sanchez-Giron, V., Serrano, A., Hernanz, J.L. and Navarrete, L. (2004). Economic assessment of three long-term tillage systems for rain fed cereal and legume production in semiarid central Spain. Soil and Tillage Research, 78, 35-44. https:// doi.org/10.1016/j.still.2004.01.001

Sarangi, S.K., Maji, B., Singh, S., Burman, D., Mandal, S., Sharma, D.K., Singh, U.S.,Ismail, A.M., Haefele, S.M. (2015). Improved nursery management furtherenhances productivity of stress tolerant rice varieties in coastal rainfedlowlands. Field Crop Research, 174, 61-70. https://doi.org/10.1016/j. fcr.2015.01.011

Shah, M.A., Manaf, A., Hussain, M., Farooq, S., Zafar-ul-Hye, M. (2013). Sulphur fertilization improves the sesame productivity and economic returns under rainfed conditions. International Journal of Agriculture and Biology, 15, 13011306.

Sieling, K., Stahl, C., Winkelmann, C., Christen, O. (2005). Growth and yield of winter wheat in the first years of a monoculture under varying $\mathrm{N}$ fertilization in NW Germany. European Journal of Agronomy, 22, 71-84. https://doi. org/10.1016/j.eja.2003.12.004

Singh, R.K., Jitendra, S.B., Triyugi, N., Yeshwant, S. and Kalyan, S. (2011). Integrated assessment of diversification of ricewheat cropping system in Indo-Gangetic plain. Archives of Agronomy and Soil Science, 57(5), 489-506. https://doi. org/10.1080/03650341003641771

Singh, Y.P., Nayak, A.K., Sharma, D.K., Gautam, R.K., Singh, R.K., Singh, R., Mishra,V.K., Paris, T., Ismail, A.M. (2014). Farmer's participatory varietal selection: asustainable crop improvement approach for the 21stcentury. Agroecology and Sustainable Food Systems, 38, 427-444. https://doi.org /10.1080/21683565.2013.870101

Smajgl, A., Ward, J., Pluschke, L. (2016). The water-food-energy nexus-realising a new paradigm. Journal of Hydrology, 533, 533-540. https://doi.org/10.1016/j.jhydrol.2015.12.033

Stanger, T.F., J.G. Lauer, and J. Chavas. (2008). The profitability 
and risk of long-term cropping systems featuring different rotations and nitrogen rates. Agronomy Journal, 100, 105113. https://doi.org/10.2134/agronj2006.0322

Stanger, T.F., Joseph, G. L. and Jean, P. C. (2006). The Profitability and Risk of Long-Term Cropping Systems Featuring Different Rotations and Nitrogen Rates. Agronomy Journal, 100(1), 105-113 https://doi.org/10.2134/agronj2006.0322

Steel, R.G.D., Torrie, J.H., Dickey, D.A. (1997). Principles and Procedures of Statistic: A Biometrical Approach. 3rd edition, pp: 400-428. Mc Graw Hill book Co. Inc. New York, USA.

Sumner, M. E. (2000). Handbook of Soil Science: Boca Raton. CRC Press. 2 148pp.

Tamimi, N., Chris, B., Helena, O., Bettina, B., Stephanie, S., Yung S.H., Sandra, M. S., Mark, T., Sonia, N. (2016). Salinity tolerance loci revealed in rice using high-throughput noninvasive phenotyping. Nature Communications, 7(13342), 1-11. https://doi.org/10.1038/ncomms13342

Tanaka, D.L., Anderson, R.L., Rao, S.C. (2005). Crop sequencing to improve use of precipitation and synergize crop growth. Agronomy Journal, 97, 385-390. https://doi. org/10.2134/agronj2005.0385

U.S. Salinity Lab. Staff. (1954). Diagnosis and Improvement of Saline and Alkali Soils. USDA Handbook 60, Washington DC, USA.

Varvel, G.E. (2000). Crop rotation and nitrogen effects on normalized grain yields in a long-term study. Agronomy Journal, 92, 938-941. https://doi.org/10.2134/agronj2000.925938x

Wassmann, R., Neue, H.U., Ladha, J.K., Aulakh, M.S. (2004). Mitigating greenhouse gas emissions from rice-wheat cropping systems in Asia. Environment, Development and Sustainability, 6, 65-90. https://doi.org/10.1023/ B:ENVI.0000003630.54494.a7

Wilson, P., Gibbons, J., Ramsden, S. (2003). The impact of cereal prices and policy on crop rotations and supply response. Journal of Agricultural Economics, 54, 313-323. https://doi. org/10.1111/j.1477-9552.2003.tb00065.x
Wyk, B.E.v., Wink, M. (2004). Medicinal Plants of the World. Timber Press, Oregon.

Yao, R.J., Yang, J.S., Zhang, T.J., Gao, P., Yu, S.P., Wang, X.P. (2013). Short-term effect of cultivation and crop rotation systems on soil quality indicators in a coastal newly reclaimed farming area. Journal of Soils and Sediments, 13(8), 1335-1350. https://doi.org/10.1007/s11368-013-0739-6

Yazar, A. (2008). Guidelines on crop management under saline conditions including seed treatments technology, crop selection and rotation. Cukurova University, Faculty of Agriculture, Adana, Turkey.

Yeo, A.R., Yeo, M.E., Flowers, S.A., Flowers, T.J. (1990). Screening of rice (Oryza sativa) genotypes for physiological characters contributing to salinity resistance, and their relationship to overall performance. Theoretical and Applied Genetics, 79(3), 377-384. https://doi.org/10.1007/ BF01186082

Zentner, R.P., Lafond, G.P., Derksen, D.A., Campbell, C.A. (2002). Tillage method and crop diversification: effect on economic returns and riskiness of cropping systems in a Thin Black Chernozem of the Canadian Prairies. Soil and Tillage Research, 67, 9-21. https://doi.org/10.1016/S01671987(02)00028-4

Zhang, M., He, Z. (2004). Long-term changes in organic carbon and nutrients of an Ultisol under rice cropping in southeast China. Geoderma, 118, 167-179. https://doi.org/10.1016/ S0016-7061(03)00191-5

Zhu, S.G., Sai, S.Q., Zhang, Y.J. (2011) Investigation and analysis on the production costs and benefits of nine kinds of grain and oil crops in northern China. Agricultural Economy, 1, 32-34.

Zou, P., Fu, J., Cao, Z. (2011). Chronosequence of paddy soils and phosphorus sorption- desorption properties. Journal of Soils and Sediments, 11, 249-259. https://doi.org/10.1007/ s11368-010-0301-8 